\title{
Determination of Triapine, A Ribonucleotide Reductase Inhibitor, In Human Plasma by Liquid Chromatography Tandem Mass Spectrometry
}

\author{
Ye Feng \\ Cleveland State University \\ Charles A. Kunos \\ Case Western Reserve University \\ Yan Xu \\ Cleveland State University, y.xu@csuohio.edu \\ Follow this and additional works at: https://engagedscholarship.csuohio.edu/scichem_facpub \\ Part of the Analytical Chemistry Commons \\ How does access to this work benefit you? Let us know!

\section{Publisher's Statement} \\ This is the accepted version of the following article: Feng, Y.; Kunos, C. A.; Xu, Y. Determination \\ of triapine, a ribonucleotide reductase inhibitor, in human plasma by liquid chromatography \\ tandem mass spectrometry. Biomedical Chromatography 2015, 29, 1380-1387., which has been \\ published in final form at http://onlinelibrary.wiley.com/doi/10.1002/bmc.3434/full
}

\section{Recommended Citation}

Feng, Ye; Kunos, Charles A.; and Xu, Yan, "Determination of Triapine, A Ribonucleotide Reductase Inhibitor, In Human Plasma by Liquid Chromatography Tandem Mass Spectrometry" (2015). Chemistry Faculty Publications. 180.

https://engagedscholarship.csuohio.edu/scichem_facpub/180

This Article is brought to you for free and open access by the Chemistry Department at EngagedScholarship@CSU. It has been accepted for inclusion in Chemistry Faculty Publications by an authorized administrator of EngagedScholarship@CSU. For more information, please contact library.es@csuohio.edu. 


\title{
Determination of triapine, a ribonucleotide reductase inhibitor, in human plasma by liquid chromatography tandem mass spectrometry
}

\author{
Ye Feng , Charles A. Kunos and Yan Xu
}

\section{Introduction}

Ribonucleotide reductase (RNR) is an essential enzyme for cell division as well as tumor growth (Finch et al., 1999), which not only catalyzes the conserved reduction of ribonucleotides to deoxyribonucleotides, but also regulates the total rate of DNA synthesis to maintain a constant ratio of DNA to cell mass during cell proliferation and DNA repair (Jordan and Reichard, 1998; Shao et al., 2006; Xu et al., 2008). There are two RNR isoforms in human (two dimers of M1-M2 subunits, or two dimers of M1-M2b subunits), and the catalytic function of the enzyme relies on the essential iron-tyrosyl radical center in $M 2$ or M2b subunits (Jordan and Reichard, 1998). Hence, it is a prime target for the development of chemotherapeutic agents.

Triapine (3-aminopyridine-2-carboxaldehyde thiosemicarbazone, or 3-AP; Fig. 1A) is a metal-ion chelator and an experimental anticancer agent, which can disrupt the catalytic iron-tyrosyl radical center in M2 or M2b subunit of RNR via the formation of triapine-Fe(III) complex (Kowol et al., 2009). Compared with hydroxyurea (HU), the only RNR-inhibitor drug currently used in chemotherapy, triapine is 1000-fold more potent for inhibition of RNR activity (Finch et al., 1999). Studies have shown that triapine has a broaderspectrum antitumor activity and can significantly decrease RNR activity in a variety of cancer cell lines including leukemia, nonsmallcell lung cancer, renal cancer and melanoma, and enhances radiation-mediated cytotoxicity in cervical and colon cancers (Alvero et al., 2006; Finch et al., 1999, 2000; Giles et al., 2003; Kuo et al., 2003; Li et al., 2001). These promising pre-clinical studies have prompted a large number of clinical trials. To date, there have been 36 clinical trials of triapine worldwide for various cancers at various stages of studies (http://www.clinicaltrials.gov/ct2/results? term=triapine\&Search=Search, accessed 14 December 2014). At the Case Comprehensive Cancer Center, the triapine studies have been focused on the investigation of sensitizing potential of triapine on radiation therapy of cervical and vaginal cancers (Kunos et al., 2009, 2010a, 2010b, 2013).

Despite the therapeutic significance of triapine, there is no validated analytical method published for quantitation of triapine in human biological samples. Several LC-UV assays have been described for the measurement of triapine in clinical studies (Mortazavi et al., 2013; Murren et al., 2003; Yee et al., 2006); however, when adopted, they often produced irreproducible results and were hindered by poor selectivity and inadequate limits of quantitation. Our recent study revealed that factors including solution $\mathrm{pH}$, metal ions, other competing chelators and buffer composition can affect the reproducibility of an LC-UV method by influencing triapine complexation reaction, and the 
<smiles>NC(=S)N/N=C/c1cnccc1N</smiles>

(A) Triapine (3-AP)<smiles>NC(=S)N/N=C/c1cnccc1F</smiles>

(B) NSC 266749 (IS)

Figure 1. The chemical structures of triapine and NSC 266749 (IS).

optimization of these factors is critical in the chromatography method development (Feng et al., 2014).

In this work, we have developed and validated a reliable and selective LC-MS/MS method based on our recent findings (Feng et al., 2014) with adequate lower limit of quantitation (LLOQ) for determination of triapine in human plasma samples. Plasma samples were prepared by direct protein precipitation with acetonitrile. The method developed has been applied to the measurement of triapine in patient samples obtained from a phase I clinical trial.

\section{Experimental}

\section{Chemicals and materials}

Triapine was provided by Vion Pharmaceuticals (New Haven, CT, USA) and used as the chemical standard for this work. 2 [(3 Fluoro 2 pyridinyl)methylene] hydrazinecarbothioamide (NSC 266749 or CAS 31181416 ) was obtained from the Developmental Therapeutics Pro gram of the National Cancer Institute at the National Institutes of Health (Bethesda, MD, USA) and used as the internal standard (IS). HPLC grade methanol, ethylenediaminetetraacetic acid disodium salt (EDTA), and ammonium hydroxide were purchased from Sigma Aldrich (St Louis, MO, USA). Ammonium bicarbonate was from EMD Chemicals (Darmstadt, Germany). Deionized water was obtained from a Barnstead Model 7148 Nanopure $^{\circledast}$ ultrapure water system (Thermo Scientific, Asheville, NC, USA). Six lots of human blank plasma (EDTA treated), six lots of human blank sera, and pooled human blank plasma were pur chased from Innovative Research (Novi, MI, USA).

\section{Preparation of stock and standard solutions}

The stock solutions of triapine $(1.00 \mathrm{mg} / \mathrm{mL})$ and NSC 266749 $(1.00 \mathrm{mg} / \mathrm{mL})$ were prepared individually by dissolving appropriate amount of each chemical in a known volume of methanol, and were kept at $-20^{\circ} \mathrm{C}$ before use. The dilution solution which was prepared for dilution of the stock solutions to working standard solutions contained $25.0 \%$ acetonitrile and 75.0\% ammonium bicarbonate EDTA (10.0 mM NH $\mathrm{HCO}_{3}$ and $1.00 \mathrm{~mm}$ EDTA, pH 8.50) buffer $(\mathrm{v} / \mathrm{v})$. The working solutions of triapine $(1.00 \mu \mathrm{g} / \mathrm{mL})$ and NSC $266749(1.00 \mu \mathrm{g} / \mathrm{mL})$ were freshly prepared by serial dilution of each stock solution with the dilution solution.

Triapine standard solutions $(5.00,10.0,15.0,20.0,50.0,100,150$, 200, 500, 800 and $1.00 \times 10^{3} \mathrm{ng} / \mathrm{mL}$ ) and NSC 266749 internal stan dard solution $(100 \mathrm{ng} / \mathrm{mL})$ were prepared individually by serial dilution of the working solutions of triapine $(1.00 \mu \mathrm{g} / \mathrm{mL})$ and NSC 266749 $(1.00 \mu \mathrm{g} / \mathrm{mL})$ with the dilution solution. These standard solutions were used for the preparation of triapine plasma calibrators and quality controls (QCs).

\section{Preparation of triapine plasma calibrators, QCs and patients' samples}

Triapine plasma calibrators $(0.250,0.500,1.00,2.50,5.00,10.0,25.0$ and $50.0 \mathrm{ng} / \mathrm{mL}$ ) and plasma quality controls (i.e. low, medium, high and dilution QCs $\quad 0.750,7.50,40.0$ and $400 \mathrm{ng} / \mathrm{mL}$ ) were prepared individu ally by mixing $200 \mu \mathrm{L}$ of pooled blank human plasma and $10.0 \mu \mathrm{L}$ of the corresponding triapine standard solution, which was 20 times the cali brator concentration. Patient plasma samples were prepared by mixing $200 \mu \mathrm{L}$ of each patient's plasma with $10.0 \mu \mathrm{L}$ of the dilution solution to match the sample matrix with those of the plasma calibrators and QCs.

Single blank plasma (or triapine plasma zero calibrator) was prepared by mixing $200 \mu \mathrm{L}$ of pooled blank human plasma with $10.0 \mu \mathrm{L}$ of the di lution solution. Double blank plasma (containing neither triapine nor the IS) was prepared by mixing $200 \mu \mathrm{L}$ of pooled blank human plasma with $20.0 \mu \mathrm{L}$ of the dilution solution.

Prior to sample deproteinization, $10.0 \mu \mathrm{L}$ of the IS solution $(100 \mathrm{ng} / \mathrm{mL})$ was added to each of the above plasma samples (e.g. calibrators includ ing zero calibrator, QCs and patient samples) except double blank plasma and mixed well.

\section{Deproteinization of plasma samples}

Each plasma sample was mixed with $880 \mu \mathrm{L}$ of acetonitrile (at a ratio of 4 to 1 ) and vortexed for $30 \mathrm{~s}$. Following by centrifugation at $15,000 \times \mathrm{g}$ for $10 \mathrm{~min}$, the supernatant was pipetted into a $1.5 \mathrm{~mL}$ microcentrifuge tube and dried in a TurboVap ${ }^{\circledR}$ LV evaporator (Caliper Life Sciences, Hopkinton, MA, USA) at $30^{\circ} \mathrm{C}$ under nitrogen gas. The resulting residue was reconstituted in $110 \mu \mathrm{L}$ of the dilution solution for LC MS/MS analysis.

\section{Instrumentation}

The LC MS/MS instrumentation system used consisted of a Shimadzu SIL 20AC autosampler (Shimadzu, Columbia, MD, USA), a Shimadzu LC 20AD HPLC unit with a Waters Xbridge Shield $\mathrm{RP}_{18}$ column $(3.5 \mu \mathrm{m} ; 2.1 \times 50 \mathrm{~mm})$ and a mobile phase containing methanol and $10.0 \mathrm{~mm}$ ammonium bicarbonate $(\mathrm{pH} 8.50)$ at a ratio of $25: 75(\mathrm{v} / \mathrm{v})$ and an AB Sciex API 3200 turbo ionspray ${ }^{\circledR}$ triple quadrupole tandem mass spectrometer (AB Sciex, Foster City, CA, USA). The system was controlled by $A B$ Sciex Analyst ${ }^{\oplus}$ (version 1.5.1) software.

The API 3200 tandem mass spectrometer was operated under the positive turbo ionspray ionization mode and was tuned by a mixture of $500 \mathrm{ng} / \mathrm{mL}$ tiapine and $500 \mathrm{ng} / \mathrm{mL}$ the IS in $50 \%$ methanol and $50 \%$ am monium bicarbonate (10.0 mM, pH 8.50) for both compound dependent and source dependent parameters. The multiple reaction monitoring (MRM) data were acquired with the following mass transitions: $\mathrm{m} / \mathrm{z} 196>121$ for triapine, and $\mathrm{m} / \mathrm{z} 199>124$ for the IS. The optimized instrument settings were as follows: curtain gas at 40; collision assisted dissociation gas at 8 ; ionization voltage at $4500 \mathrm{~V}$; source temperature at 700 ; sheath gas at 50 ; desolvation gas at 40 ; desolvation potential at 40; entrance potential at 4; collision energy at 23; collision cell exit potential at 2; and resolution at unit.

The separation of triapine and the IS was accomplished by isocratic elution with the mobile phase at a flow rate of $0.300 \mathrm{~mL} / \mathrm{min}$. Prior to ini tial sample analysis, the column was equilibrated with the mobile phase at the flow rate for at least $30 \mathrm{~min}$. During each run, $10.0 \mu \mathrm{L}$ of reconstituted sample was injected into the system by the autosampler set at $4.0^{\circ} \mathrm{C}$. The two position switch valve on the API 3200 tandem mass spectrometer was programmed to switch to the waste for the first $1.2 \mathrm{~min}$ and then switch to the mass spectrometer. Quantitation of triapine was carried out by the MRM mode of the tandem mass spec trometer, and the total instrument run time for each sample analysis was $4 \mathrm{~min}$.

\section{Method validation}

The LC MS/MS method developed was validated in human plasma according to the US Food and Drug Administration (2001) guidance for industry on bioanalytical method validation and the white paper of the 2006 bioanalytical method validation workshop (Bansal and DeStefano, 
2007) in terms of selectivity, LLOQ, recovery, matrix effect, linear re sponse range, accuracy and precision, as well as stability for both short term sample processing and long term sample storage.

\section{Selectivity and LLOQ}

The selectivity of this method was evaluated by observing any interfernts at the same retention times and mass transitions of the analyte and the IS in six individual blank plasma and pooled blank plasma matrices, as well as in the pre dosed plasma from patients. The LLOQ of the method was defined as the lowest concentration of triapine plasma calibrator of the calibration curve with accuracy and precision $\leq \pm 20$ and $20 \%$, which was validated in six individual plasma, and pooled plasma matrices.

\section{Matrix factor and recovery}

The absolute matrix factor (MF) of triapine (or the IS) was determined by the mean peak area of triapine (or the IS) at a specified concentration in the deproteinized plasma matrix over that of triapine (or the IS) at the concentration in the mobile phase. The IS normalized MF was deter mined by the absolute MF of triapine over that of the IS. For this study, triapine QCs at two concentrations $(0.750$ and $40.0 \mathrm{ng} / \mathrm{mL})$ with a fixed concentration of the $\mathrm{IS}(5.00 \mathrm{ng} / \mathrm{mL})$ were prepared in six individual deproteinized plasma matrices and in the mobile phase.

The absolute recovery of triapine (or the IS) was determined by the mean peak area of triapine (or the IS) at a specific concentration in plasma matrix over the mean peak area of triapine (or the IS) at the con centration in the deproteinized plasma matrix multiplied by $100 \%$. The IS normalized recovery was determined by the absolute recovery of triapine over that of the IS multiplying by $100 \%$. For this study, triapine QCs at three concentrations $(0.750,7.50$ and $40.0 \mathrm{ng} / \mathrm{mL}$ ) with a fixed concentration of the IS $(5.00 \mathrm{ng} / \mathrm{mL})$ were prepared in the pooled human plasma and the deproteinized pooled human plasma.

\section{Calibration curve}

The triapine calibration curve in human plasma was established using double blank (plasma matrix with neither triapine nor the IS), single blank (plasma matrix with only the IS) and eight nonzero plasma calibra tors at the concentrations $0.250,0.500,1.00,2.50,5.00,10.0,25.0$ and
$50.0 \mathrm{ng} / \mathrm{mL}$ with the IS at the concentration $5.00 \mathrm{ng} / \mathrm{mL}$. The peak area ratios of triapine to the IS $(y)$ were plotted against triapine calibrator con centrations $(x)$ with $1 / x$ weighting.

\section{Accuracy, precision and dilution study}

Accuracy was expressed as percentage relative error (RE) and precision as the coefficient of variation (CV). In this work, the inter assay preci sion and accuracy were assessed by five parallel analyses of five iden tical QC samples at each of four QC concentrations $(0.750,7.50,40.0$ and $400 \mathrm{ng} / \mathrm{mL}$ ). The intra assay precision and accuracy were assessed by five replicate analyses of each QC samples. The above studies also included the dilution study where the dilution QCs $(400 \mathrm{ng} / \mathrm{mL})$ were prepared and analyzed after 10 fold dilution by the pooled human blank plasma.

\section{Stability study}

The stability of triapine was investigated using stock and working solu tions $(1.00 \mathrm{mg} / \mathrm{mL}$ and $1.00 \mu \mathrm{g} / \mathrm{mL})$ and plasma low and high QCs $(0.750$ and $40.0 \mathrm{ng} / \mathrm{mL})$, and the stability of NSC 266749 was also deter mined separately using NSC 266749 standard solution $(100 \mathrm{ng} / \mathrm{mL})$ and plasma sample containing $5.00 \mathrm{ng} / \mathrm{mL}$ of NSC 266749 . In the NSC 266749 stability studies, triapine was used as the IS.

Stabilities of triapine stock and working solutions, triapine plasma QCs, NSC 266749 standard solution and plasma samples were assessed during short term ( 6 and $24 \mathrm{~h}$ ) storage, standing on the bench top at $23^{\circ} \mathrm{C}$ and in the autosampler at $4^{\circ} \mathrm{C}$ (post preparative); during three freeze thaw cycles (where the samples were frozen at $-20^{\circ} \mathrm{C}$ for at least $24 \mathrm{~h}$ and thawed at room temperature, $23^{\circ} \mathrm{C}$, unassisted); and during long term storage (30 days) at $-20^{\circ} \mathrm{C}$. The stabilities of triapine and NSC 266749 were determined by comparing the mean peak area ratios of analyte to IS in the test sample with those of freshly prepared samples, and expressed as percentages. For this study, all experiments were done in five replicates.

\section{Method application}

The LC MS/MS method developed was tested for the measurement of triapine in patient plasma samples collected from a previous phase I

\section{(A) $[\text { Triapine }+\mathbf{H}]^{+}$}

(C) Product ions of $\mathrm{m} / \mathrm{z} 196.1$ (Triapine)

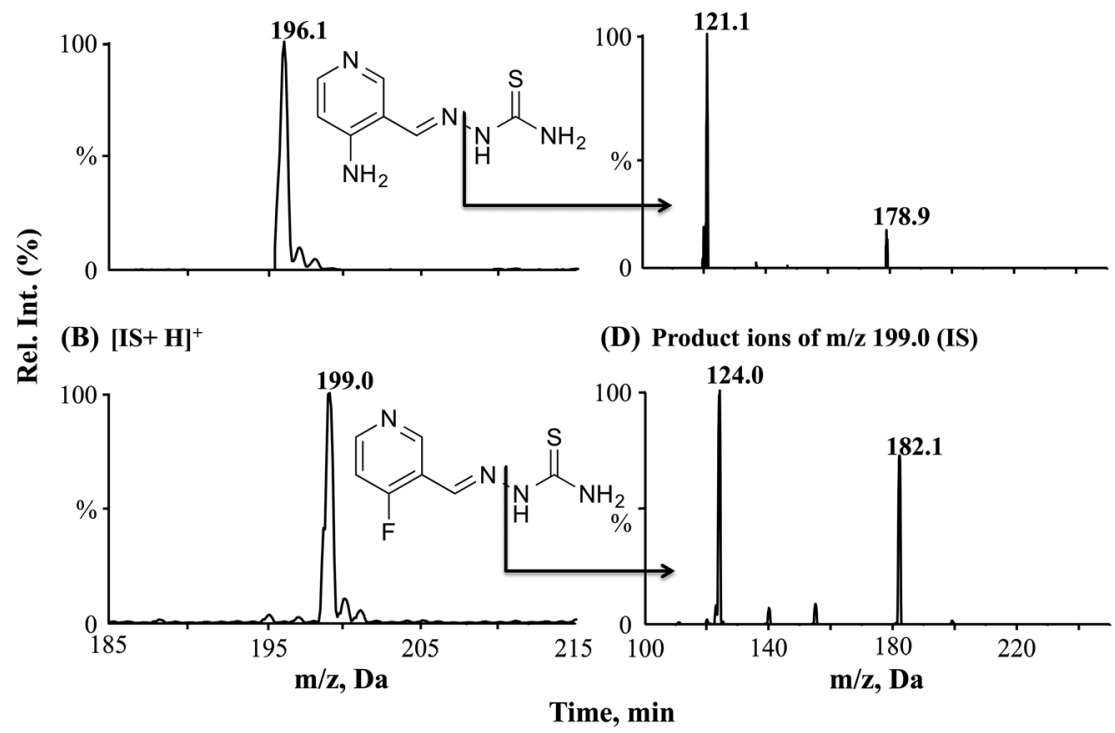

Figure 2. The mass spectra of triapine and the IS. The experimental conditions were described in the 'Instrumentation' section under the 'Experimental'. 
clinical trial of pelvic radiation, weekly cisplatin and triapine for locally advanced cervical cancer (Kunos et al., 2010a, 2010b), where patients were given triapine by a $2 \mathrm{~h}$ intravenous (i.v.) infusion at the dose of $25 \mathrm{mg} / \mathrm{m}^{2}$ three times a week for 5 weeks. Blood samples were collected on days 1 and 10 in heparinized tubes at the following time points: 0 (pre dose), 2, 4, 6 and $24 \mathrm{~h}$ after the start of $2 \mathrm{~h}$ i.v. infusion. Plasma sam ples were harvested by a refrigerated centrifuge, and then stored at $-80^{\circ} \mathrm{C}$ before analysis.

In the analysis, patient samples together with 10 calibrators (i.e. double and single blank, and eight nonzero) and a set of QCs at low, medium and high concentrations (i.e. $0.750,7.50$ and $40.0 \mathrm{ng} / \mathrm{mL}$ ) were first prepared, deproteinized and processed according to the procedures described in the Experimental section, then analyzed by the validated method. The patient samples having concentrations beyond the upper limit of quantitation were re run with the dilution QC after 1:10 dilution with the pooled human blank plasma.

\section{Results and discussion}

\section{Mass spectrometric detection}

In this work, the optimization of triapine and the IS signal responses was done using the 'auto-tune' function of AB Sciex Analyst software (version 1.5.1). Since triapine and the IS more easily give their protonated than deprotonated forms in electrospray ionization (ESI), the positive ESI was used for triapine identification and quantification. As shown in Fig. 2(A and C), the predominated tirapine and IS molecular ions were at $\mathrm{m} / \mathrm{z} 196$ and $\mathrm{m} / \mathrm{z}$ 199, respectively. These protonated molecules could further be broken down into product ions by collision with nitrogen gas and produced the predominant product ions at $\mathrm{m} / \mathrm{z} 121$ and $m / z 124$ (Fig. 2B and D). Therefore, the mass transitions at $\mathrm{m} / \mathrm{z} 196>121$ for triapine and $\mathrm{m} / \mathrm{z} 199>124$ for the IS were chosen for quantitation of triapine by MRM mode.

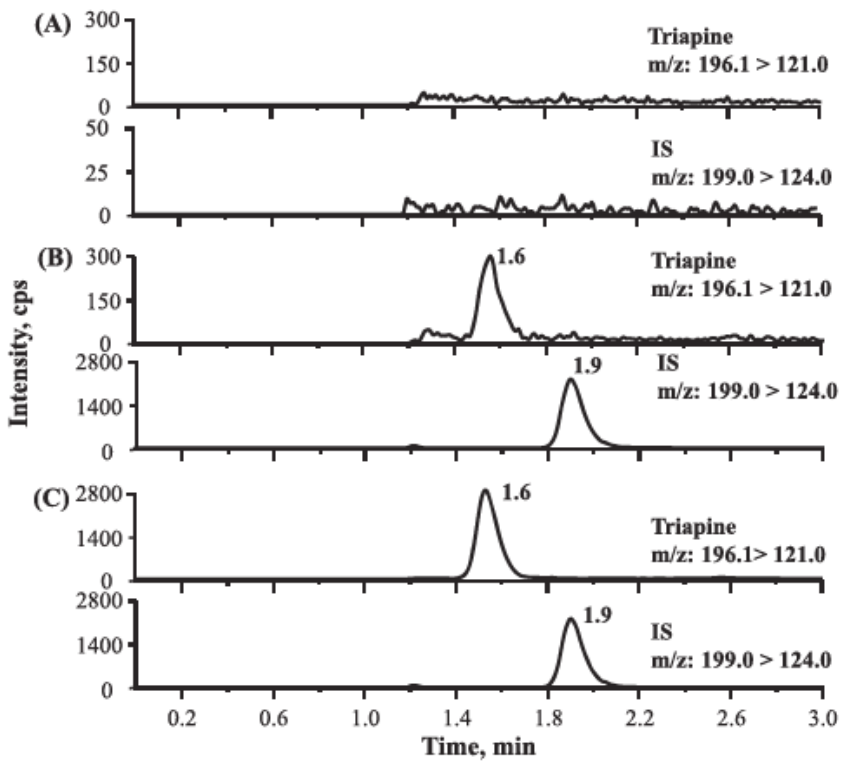

Figure 3. The representative multiple reaction monitoring chromato grams. (A) Double blank plasma; (B) $0.250 \mathrm{ng} / \mathrm{mL}$ triapine plasma calibra tor (with $5.00 \mathrm{ng} / \mathrm{mL}$ IS); and (C) $2.50 \mathrm{ng} / \mathrm{mL}$ triapine plasma calibrator (with $5.00 \mathrm{ng} / \mathrm{mL}$ IS).

\section{Liquid chromatographic separation}

In this work, separation of triapine and the IS was tested on several analytical columns, including a Waters X-Terra RP 18 $\left(2.1 \times 150 \mathrm{~mm}, 5 \mu \mathrm{m}\right.$ particle size), a Waters $\mathrm{X}$-Bridge $\mathrm{RP}_{18}$ (2.0 $\times 50 \mathrm{~mm}, 5 \mu \mathrm{m}$ particle size), a Waters X-Bridge AQ $(2.0 \times 50 \mathrm{~mm}, 5 \mu \mathrm{m}$ particle size) and a Waters X-Bridge Phenyl $(2.0 \times 50 \mathrm{~mm}, 5 \mu \mathrm{m}$ particle size), with a mobile phase containing $25 \%$ organic solvent (either methanol or acetonitrile) and $75 \%$ ammonium bicarbonate $(10.0 \mathrm{mM}, \mathrm{pH} 8.50)$ at a flow rate of $0.300 \mathrm{~mL} / \mathrm{min}$. Although reasonable retention time and baseline resolution were achieved on all columns tested with either organic modifier, the Waters $\mathrm{X}$-Bridge $\mathrm{RP}_{18}$ column and methanol solvent were chosen for the latter method development because they gave greater separation efficiency and detection sensitivity for triapine and the IS. The optimal separation of triapine and the IS was achieved on a Waters X-Bridge $\mathrm{RP}_{18}$ column at 1.6 and 1.9 min using a mobile phase containing $25 \%$ methanol and $75 \%$ ammonium bicarbonate $(10.0 \mathrm{mM}$, $\mathrm{pH} 8.50$, v/v; Fig. 3).

\section{EDTA}

Triapine is a metal-ion chelator, and can easily react with metal ions in an aqueous solution (Feng et al., 2014). Our experimental data indicated that even the trace metal ions in the presence of the deionized water $(18.2 \mathrm{M} \Omega \mathrm{cm})$ obtained from a Barnstead Nanopure Water System could affect the reproducibility of analytical signal of triapine by LC-MS/MS, unless a stronger metal-ion chelator (e.g. EDTA) was present in the same solution

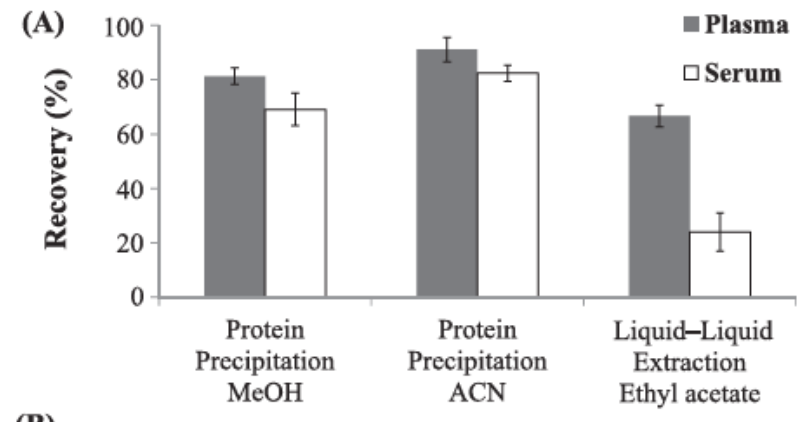

(B)

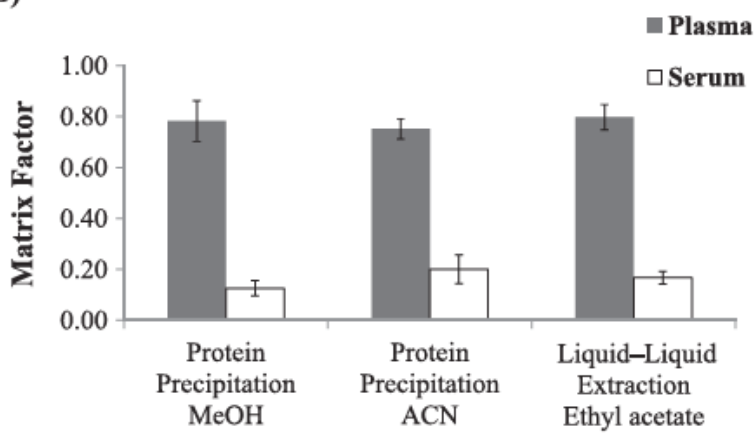

Figure 4. Comparison of matrix effect and recovery of triapine from hu man plasma vs serum by different sample preparation protocols. Each column represents the mean \pm SD from six lots of each sample matrix. Three sample preparation protocols include: (1) protein precipitation by methanol $(1: 4 ; v / v)$; (2) acetonitrile $(1: 4 ; v / v)$; and (3) liquid liquid extraction by acetyl acetate $(1: 2 ; \mathrm{v} / \mathrm{v})$. The triapine concentration was $7.50 \mathrm{ng} / \mathrm{mL}$ in each plasma and serum matrix. 
to preserve triapine from complexation. In this work, a dilution solution containing $25.0 \%$ acetonitrile and $75.0 \%$ ammonium bicarbonate-EDTA buffer (10.0 $\mathrm{mm} \mathrm{NH}_{4} \mathrm{HCO}_{3}$ and $1.00 \mathrm{mM}$ EDTA, $\mathrm{pH}$ 8.50) was used for preparation of triapine working solution from its stock in methanol, as well as triapine standards from the working solution. It is also worth noting that triapine working and standard solutions prepared in Ultrapure HPLC-grade bottled water from Fisher Scientific (Fair Lawn, NJ, USA) could also give reproducible analytical signal if it was not contaminated by metal ions.

\section{Plasma samples vs serum samples}

Because EDTA can preserve triapine from complexation with metal ions, a comparison study was conducted on the absolute

Table 1. Accuracy and precision of triapine at lower limit of quantitation (LLOQ) in six lots of human plasmas $(n=5)$

Plasma Nominal Measured SD Precision Accuracy

matrix [triapine] [triapine] $(\mathrm{ng} / \mathrm{mL})(\mathrm{CV}, \%)^{\mathrm{a}} \quad(\mathrm{RE}, \%)^{\mathrm{b}}$ $(\mathrm{ng} / \mathrm{mL}) \quad(\mathrm{ng} / \mathrm{mL})$

\begin{tabular}{lllllr}
\hline Lot 1 & 0.250 & 0.225 & 0.004 & 2 & -10 \\
Lot 2 & 0.250 & 0.26 & 0.02 & 8 & 4 \\
Lot 3 & 0.250 & 0.26 & 0.01 & 4 & 4 \\
Lot 4 & 0.250 & 0.248 & 0.007 & 3 & -1 \\
Lot 5 & 0.250 & 0.261 & 0.007 & 3 & 4 \\
Lot 6 & 0.250 & 0.250 & 0.008 & 3 & 0 \\
Mean & 0.250 & 0.250 & 0.004 & 2 & 0
\end{tabular}

(6 lots)

${ }^{\mathrm{a}} \mathrm{CV}=$ (standard deviation $/$ mean $) \times 100 \%$.

${ }^{\mathrm{b}} \mathrm{RE}=[($ measured - nominal $) /$ nominal $] \times 100 \%$. recovery and matrix effect of triapine from EDTA-treated human plasma and serum samples using two types of preparation methods, protein precipitation and liquid-liquid extraction. In this work, triapine plasma and serum samples (at $7.50 \mathrm{ng} / \mathrm{mL}$ ) were prepared by spiking triapine standard solution in six lots of human blank plasma and six lots of human blank serum. These samples were prepared by protein precipitation with acetonitrile and methanol, as well as liquid-liquid extraction with acetyl acetate. As shown in Fig. 4, the absolute recoveries of triapine were consistently higher from EDTA-treated plasma matrices (67-91\%) than those from serum matrices (24-69\%) by both types of sample preparation methods, and the absolute matrix factors were much closer to unity for plasma samples $(0.750-0.800)$ than those of serum samples $(0.120-0.200)$. Furthermore, protein precipitation with 4 volumes of acetonitrile produced greater recovery for triapine and comparable matrix factor among the sample preparation methods. Therefore, EDTA-treated plasma samples and protein precipitation by acetonitrile were used for the method development and sample preparation in the subsequent work. For clinical study of triapine, EDTA-treated tubes are highly recommended for blood collection.

\section{Selectivity and LLOQ}

The LC-MS/MS method developed was highly selective. As illustrated in Fig. 3(A), there were no detectable interferents observed at the retention times and mass transitions of triapine and the IS from six individual plasma and the pooled plasma matrices, as well as the pre-dosed plasma from patients in a phase I clinical trial (Kunos et al., 2010a, 2010b).

The LLOQ of the method for quantitation of tripaine in human plasma was $0.250 \mathrm{ng} / \mathrm{mL}$, which had signal-to-noise ratio of 23.5 Fig. 3B). Table 1 summarized the accuracy and precision of the

Table 2. Matrix effect of triapine in six individual lots of blank human plasma $(n=5)$

\begin{tabular}{|c|c|c|c|c|c|c|c|c|}
\hline $\begin{array}{l}\text { Plasma } \\
\text { matrix }\end{array}$ & $\begin{array}{c}\text { [Triapine] } \\
(\mathrm{ng} / \mathrm{mL})\end{array}$ & $\begin{array}{c}\mathrm{PA}_{\text {Triapine }}{ }^{\mathrm{a}} \text { in } \\
\text { extracted plasma } \\
\pm \mathrm{SD}\left(\times 10^{3}\right)\end{array}$ & $\begin{array}{l}\mathrm{PA}_{\text {Triapine }} \text { in } \\
\text { mobile phase } \\
\pm \mathrm{SD}\left(\times 10^{3}\right)\end{array}$ & $\begin{array}{c}M_{\text {Triapine }}{ }^{b} \\
\pm S D^{c}\end{array}$ & $\begin{array}{c}\mathrm{PA}_{\mathrm{IS}}{ }^{\mathrm{d}} \text { in } \\
\text { extracted plasma } \\
\pm \mathrm{SD}\left(\times 10^{3}\right)\end{array}$ & $\begin{array}{c}\mathrm{PA}_{\mathrm{IS}} \text { in } \\
\text { mobile phase } \\
\pm \mathrm{SD}\left(\times 10^{3}\right)\end{array}$ & $\begin{array}{l}M_{I S}{ }^{e} \\
\pm S D\end{array}$ & $\begin{array}{c}\text { IS normalized } \\
M^{f} \pm S D\end{array}$ \\
\hline \multirow[t]{2}{*}{ Lot 1} & 0.750 & $4.9 \pm 0.4$ & $6.4 \pm 0.2$ & $0.77 \pm 0.07$ & $22 \pm 2$ & $27.6 \pm 0.5$ & $0.80 \pm 0.07$ & $1.0 \pm 0.1$ \\
\hline & 40.0 & $265 \pm 5$ & $362 \pm 2$ & $0.73 \pm 0.01$ & $21.8 \pm 0.8$ & $28.3 \pm 0.3$ & $0.77 \pm 0.03$ & $0.95 \pm 0.04$ \\
\hline \multirow[t]{2}{*}{ Lot 2} & 0.750 & $5.0 \pm 0.3$ & $6.4 \pm 0.2$ & $0.78 \pm 0.05$ & $22 \pm 1$ & $27.6 \pm 0.5$ & $0.80 \pm 0.04$ & $0.98 \pm 0.08$ \\
\hline & 40.0 & $2.7 \times 10^{2} \pm 1 \times 10^{1}$ & $362 \pm 2$ & $0.75 \pm 0.03$ & $21.5 \pm 0.7$ & $28.3 \pm 0.3$ & $0.76 \pm 0.03$ & $0.99 \pm 0.06$ \\
\hline \multirow[t]{2}{*}{ Lot 3} & 0.750 & $4.5 \pm 0.2$ & $6.4 \pm 0.2$ & $0.70 \pm 0.04$ & $21 \pm 1$ & $27.6 \pm 0.5$ & $0.76 \pm 0.04$ & $0.92 \pm 0.07$ \\
\hline & 40.0 & $243 \pm 6$ & $362 \pm 2$ & $0.67 \pm 0.02$ & $19.9 \pm 0.5$ & $28.3 \pm 0.3$ & $0.70 \pm 0.02$ & $0.96 \pm 0.04$ \\
\hline \multirow[t]{2}{*}{ Lot 4} & 0.750 & $4.4 \pm 0.3$ & $6.4 \pm 0.2$ & $0.69 \pm 0.05$ & $20 \pm 2$ & $27.6 \pm 0.5$ & $0.72 \pm 0.07$ & $1.0 \pm 0.1$ \\
\hline & 40.0 & $206 \pm 8$ & $362 \pm 2$ & $0.57 \pm 0.02$ & $18 \pm 1$ & $28.3 \pm 0.3$ & $0.64 \pm 0.04$ & $0.89 \pm 0.06$ \\
\hline \multirow[t]{2}{*}{ Lot 5} & 0.750 & $4.7 \pm 0.2$ & $6.4 \pm 0.2$ & $0.73 \pm 0.04$ & $19 \pm 1$ & $27.6 \pm 0.5$ & $0.69 \pm 0.04$ & $1.06 \pm 0.08$ \\
\hline & 40.0 & $2.4 \times 10^{2} \pm 3 \times 10^{1}$ & $362 \pm 2$ & $0.66 \pm 0.08$ & $19 \pm 2$ & $28.3 \pm 0.3$ & $0.67 \pm 0.07$ & $1.0 \pm 0.1$ \\
\hline \multirow[t]{2}{*}{ Lot 6} & 0.750 & $4.5 \pm 0.2$ & $6.4 \pm 0.2$ & $0.70 \pm 0.04$ & $19.6 \pm 0.9$ & $27.6 \pm 0.5$ & $0.71 \pm 0.04$ & $0.99 \pm 0.08$ \\
\hline & 40.0 & $2.3 \times 10^{2} \pm 1 \times 10^{1}$ & $362 \pm 2$ & $0.64 \pm 0.03$ & $19.6 \pm 0.2$ & $28.3 \pm 0.3$ & $0.69 \pm 0.01$ & $0.93 \pm 0.05$ \\
\hline
\end{tabular}

${ }^{\mathrm{a}} \mathrm{PA}_{\text {Triapine }}=$ mean peak area of triapine.

${ }^{\mathrm{b}_{\mathrm{MF}}} \mathrm{F}_{\text {Triapine }}=\left(\mathrm{PA}_{\text {Triapine }}\right.$ in extracted plasma matrix $) /\left(\mathrm{PA}_{\text {Triapine }}\right.$ in mobile phase $)$.

$c_{y}\left( \pm s_{y}\right)=\left[a\left( \pm s_{a}\right) / b\left( \pm s_{b}\right)\right], s_{y}=y \times \sqrt{ }\left[\left(s_{a} / a\right)^{2}+\left(s_{b} / b^{2}\right]\right.$.

${ }^{\mathrm{d}} \mathrm{PA}_{\mathrm{IS}}=$ mean peak area of IS.

${ }^{{ }^{M}} \mathrm{MF}_{I S}=\left(\mathrm{PA}_{\mathrm{IS}}\right.$ in extracted plasma matrix $) /\left(\mathrm{PA}_{\mathrm{IS}}\right.$ in mobile phase $)$.

${ }^{\mathrm{f}} \mathrm{IS}$ normalized $\mathrm{MF}=\mathrm{MF}_{\text {Triapine }} / \mathrm{MF}_{\mathrm{IS}}$. 
Table 3. Recovery of triapine in pooled human plasma $(n=5)$

\begin{tabular}{|c|c|c|c|c|c|c|c|}
\hline $\begin{array}{l}\text { [Triapine] } \\
(\mathrm{ng} / \mathrm{mL})\end{array}$ & $\begin{array}{l}\mathrm{PA}_{\text {Triapine }}{ }^{\mathrm{a}} \\
\text { in plasma } \\
\pm \mathrm{SD}\left(\times 10^{3}\right)\end{array}$ & $\begin{array}{l}\mathrm{PA}_{\text {Triapine }} \text { in } \\
\text { extracted plasma } \\
\pm \mathrm{SD}\left(\times 10^{3}\right)\end{array}$ & $\begin{array}{c}\text { Recovery }_{\text {Triapine }}{ }^{\mathrm{b}} \\
\pm \mathrm{SD}(\%)\end{array}$ & $\begin{aligned} & \mathrm{PA}_{\mathrm{IS}}{ }^{\mathrm{C}} \text { in } \\
& \text { plasma } \\
\pm & \mathrm{SD}\left(\times 10^{3}\right)\end{aligned}$ & $\begin{array}{c}\mathrm{PA}_{\mathrm{IS}} \text { in } \\
\text { extracted plasma } \\
\pm \mathrm{SD}\left(\times 10^{3}\right)\end{array}$ & $\begin{array}{l}\text { Recovery }_{\text {IS }}{ }^{d} \\
\pm \text { SD (\%) }\end{array}$ & $\begin{array}{l}\text { IS normalized } \\
\text { recovery } \\
\pm \text { SD (\%) }\end{array}$ \\
\hline 0.750 & $3.2 \pm 0.2$ & $3.6 \pm 0.1$ & $89 \pm 6$ & $13.6 \pm 0.7$ & $15.5 \pm 0.4$ & $88 \pm 5$ & $101 \pm 9$ \\
\hline 7.50 & $37.8 \pm 0.8$ & $41.5 \pm 0.6$ & $91 \pm 2$ & $13.4 \pm 0.3$ & $15.3 \pm 0.4$ & $88 \pm 3$ & $103 \pm 4$ \\
\hline 40.0 & $214 \pm 5$ & $230 \pm 5$ & $93 \pm 3$ & $13.9 \pm 0.3$ & $15.6 \pm 0.2$ & $89 \pm 2$ & $104 \pm 4$ \\
\hline
\end{tabular}

${ }^{\mathrm{a}} \mathrm{PA}_{\text {Triapine }}=$ mean peak area of triapine.

${ }^{\mathrm{b}}$ Recovery ${ }_{\text {Triapine }}=\left[\left(\mathrm{PA}_{\text {Triapine }}\right.\right.$ in plasma matrix $) /\left(\mathrm{PA}_{\text {Triapine }}\right.$ in extracted plasma matrix $\left.)\right] \times 100 \%$.

${ }^{\mathrm{C}} \mathrm{PA}_{\mathrm{IS}}=$ mean peak area of IS.

${ }^{d}$ Recovery ${ }_{I S}=\left[\left(P_{I S}\right.\right.$ in plasma matrix $) /\left(P A_{I S}\right.$ in extracted plasma matrix $\left.)\right] \times 100 \%$.

${ }^{\mathrm{e}}$ IS normalized recovery $=\left[(\right.$ Recovery Triapine $) /\left(\right.$ Recovery $\left.\left.{ }_{I S}\right)\right] \times 100 \%$.

method at LLOQ. By five replicate measurements of each plasma matrix from six lots, the accuracy and precision were $\leq \pm 10$ and $\leq 8 \%$, respectively. These values were lower than those of the industry limits recommended by US Food and Drug Administration $(\leq \pm 20$ and $\leq 20 \%$ ), which implied that the actual LLOQ of the method could be $<0.250 \mathrm{ng} / \mathrm{mL}$ if it was validated when needed.

\section{Matrix effect and recovery}

Matrix effect was assessed by the MF using six independent lots of human plasmas. As shown in Table 2, the absolute MFs of triapine and the IS were $0.57-0.78$ and $0.64-0.80$, respectively, and the IS normalized MFs were near unity (0.92-1.06). Hence, the matrix effect of human plasma on the analytical signals could be effectively corrected by the use of the IS.

The recovery data of triapine in pooled human plasma is shown in Table 3. The absolute recoveries of triapine and the IS were 89-93 and 88-89\%, respectively, and the IS normalized recovery was $101-104 \%$. These results indicated that the protein precipitation procedure was sufficient to recover the analyte and the IS from human plasma.

\section{Linearity}

The linear regression equation obtained from six batches over 3 days was $y=0.373( \pm 0.012) x-0.00107( \pm 0.00034)$ over the

Table 4. Accuracy and precision of plasma calibrators over three different days $(n=6)$

\begin{tabular}{lccccc}
$\begin{array}{l}\text { Sample } \\
\text { matrix }\end{array}$ & $\begin{array}{c}\text { Nominal } \\
\text { [triapine] } \\
(\mathrm{ng} / \mathrm{mL})\end{array}$ & $\begin{array}{c}\text { Measured } \\
\text { [triapine] } \\
(\mathrm{ng} / \mathrm{mL})\end{array}$ & $\begin{array}{c}\mathrm{SD} \\
(\mathrm{ng} / \mathrm{mL})\end{array}$ & $\begin{array}{c}\text { Precision } \\
(\mathrm{CV}, \%)\end{array}$ & $\begin{array}{c}\text { Accuracy } \\
(\mathrm{RE}, \%)\end{array}$ \\
\hline Pooled & 0.250 & 0.25 & 0.01 & 4 & 0 \\
human & 0.500 & 0.50 & 0.03 & 6 & 0 \\
plasma & 1.00 & 0.98 & 0.08 & 8 & -2 \\
& 2.50 & 2.5 & 0.1 & 4 & 1 \\
& 5.00 & 4.9 & 0.4 & 8 & -2 \\
& 10.0 & 9.8 & 0.5 & 5 & -2 \\
& 25.0 & 24 & 2 & 8 & -4 \\
& 50.0 & 53 & 2 & 4 & 6
\end{tabular}

range $0.250-50.0 \mathrm{ng} / \mathrm{mL}$ with individual correlation coefficients $>0.999$. The accuracy and precision of individual plasma calibrators as summarized in Table 4 were $\leq \pm 6$ and $\leq 8 \%$, respectively.

\section{Accuracy, precision and dilution integrity}

As shown in Table 5 , the accuracy and precision were $\leq \pm 8$ and $\leq 5 \%$ for the intra-assay study and $\leq \pm 7$ and $\leq 4 \%$ for the interassay study, indicating the method developed was accurate and precise. In this study, dilution QC (400 ng/mL) was included because some of the patient plasma samples had triapine concentrations beyond the upper limit of quantitation (50.0 ng/mL) of the method. The accuracy and precision data of the dilution QC ( $\leq \pm 2$ and $\leq 0.5 \%$ for the intra-assay study and $\leq \pm 7$ and $\leq 1 \%$ for the inter-assay study) indicated that the integrity of plasma sample could be preserved after sample dilution.

Table 5. Intra- and inter-run accuracy and precision for triapine in pooled human plasma

\begin{tabular}{lcccc}
$\begin{array}{l}\text { Nominal } \\
\text { Triapine }] \\
(\mathrm{ng} / \mathrm{mL})\end{array}$ & $\begin{array}{c}\text { Measured } \\
{[\text { Triapine }]} \\
(\mathrm{ng} / \mathrm{mL})\end{array}$ & $\begin{array}{c}\mathrm{SD} \\
(\mathrm{ng} / \mathrm{mL})\end{array}$ & $\begin{array}{c}\text { Precision } \\
(\mathrm{CV}, \%)\end{array}$ & $\begin{array}{c}\text { Accuracy } \\
(\mathrm{RE}, \%)\end{array}$ \\
\hline
\end{tabular}

\begin{tabular}{|c|c|c|c|c|}
\hline \multicolumn{5}{|c|}{ Intra-run $^{\mathrm{a}}$ ( $n=5$ replicates) } \\
\hline 0.750 & 0.74 & 0.02 & 3 & -1 \\
\hline 7.50 & 8.1 & 0.1 & 1 & 8 \\
\hline 40.0 & 40 & 2 & 5 & -1 \\
\hline $400^{c}$ & 406 & 2 & 0.5 & 2 \\
\hline \multicolumn{5}{|c|}{ Inter-run $^{\mathrm{b}}$ ( $n=5$ parallels) } \\
\hline 0.750 & 0.72 & 0.01 & 1 & -4 \\
\hline 7.50 & 7.0 & 0.3 & 4 & -7 \\
\hline 40.0 & 38.2 & 0.9 & 2 & -4 \\
\hline $400^{c}$ & 429 & 3 & 1 & 7 \\
\hline
\end{tabular}

${ }^{a}$ Each datum point calculated by five replicate measurements of each quality control (QC) sample.

${ }^{\mathrm{b}}$ Each datum point calculated by five parallel measurements from five identical QCs.

'Dilution QC was measured by 10x dilution with blank pooled human plasma. 
Table 6. Stabilities of triapine and NSC 266749 under various conditions $(n=5)^{\mathrm{a}}$

\begin{tabular}{|c|c|c|c|c|c|}
\hline \multirow[t]{2}{*}{ Test conditions } & \multirow[t]{2}{*}{ Temperature $\left({ }^{\circ} \mathrm{C}\right)$} & & \multicolumn{3}{|c|}{ Recovery \pm SD (\%) } \\
\hline & & & $6 \mathrm{~h}$ & $24 \mathrm{~h}$ & \\
\hline \multirow{5}{*}{ Bench-top } & & Triapine & & & \\
\hline & 23 & $\begin{array}{l}\text { Stock solution }{ }^{b} \\
\left(1.00 \times 10^{6} \mathrm{ng} / \mathrm{mL}\right)\end{array}$ & $101 \pm 1$ & $100 \pm 4$ & \\
\hline & & $\begin{array}{l}\text { Working solution }{ }^{b} \\
\left(1.00 \times 10^{3} \mathrm{ng} / \mathrm{mL}\right)\end{array}$ & $106 \pm 3$ & $100 \pm 5$ & \\
\hline & & Plasma low QC ${ }^{c}$ & $88 \pm 2$ & $68 \pm 3$ & \\
\hline & & Plasma high $\mathrm{QC}^{\mathrm{c}}$ & $90 \pm 2$ & $61 \pm 5$ & \\
\hline \multirow[t]{2}{*}{ Autosampler } & 4 & Plasma low QC & $96 \pm 1$ & $94 \pm 8$ & \\
\hline & & Plasma high QC & $87 \pm 1$ & $83 \pm 5$ & \\
\hline \multirow[t]{2}{*}{ Three freeze-thaw cycles } & -20 to 23 & Plasma low QC & & & $96 \pm 2$ \\
\hline & & Plasma high QC & & & $98 \pm 5$ \\
\hline \multirow[t]{3}{*}{ Long-term (30 days) } & -20 & Plasma low QC & & & $86 \pm 6$ \\
\hline & & Plasma high QC & & & $91 \pm 5$ \\
\hline & & NSC $266749^{\mathrm{b}}$ & & & \\
\hline \multirow[t]{2}{*}{ Bench-top } & 23 & Solution (100 ng/mL) & $105 \pm 2$ & $100 \pm 6$ & \\
\hline & & Plasma $(5.00$ ng/mL) & $89 \pm 5$ & $84 \pm 5$ & \\
\hline Autosampler & 4 & Plasma (5.00 ng/mL) & $87 \pm 3$ & $93 \pm 5$ & \\
\hline Three freeze-thaw cycles & -20 to 23 & Plasma $(5.00$ ng/mL) & & & $92 \pm 4$ \\
\hline Long-term (30 days) & -20 & Plasma (5.00 ng/mL) & & & $88 \pm 7$ \\
\hline
\end{tabular}
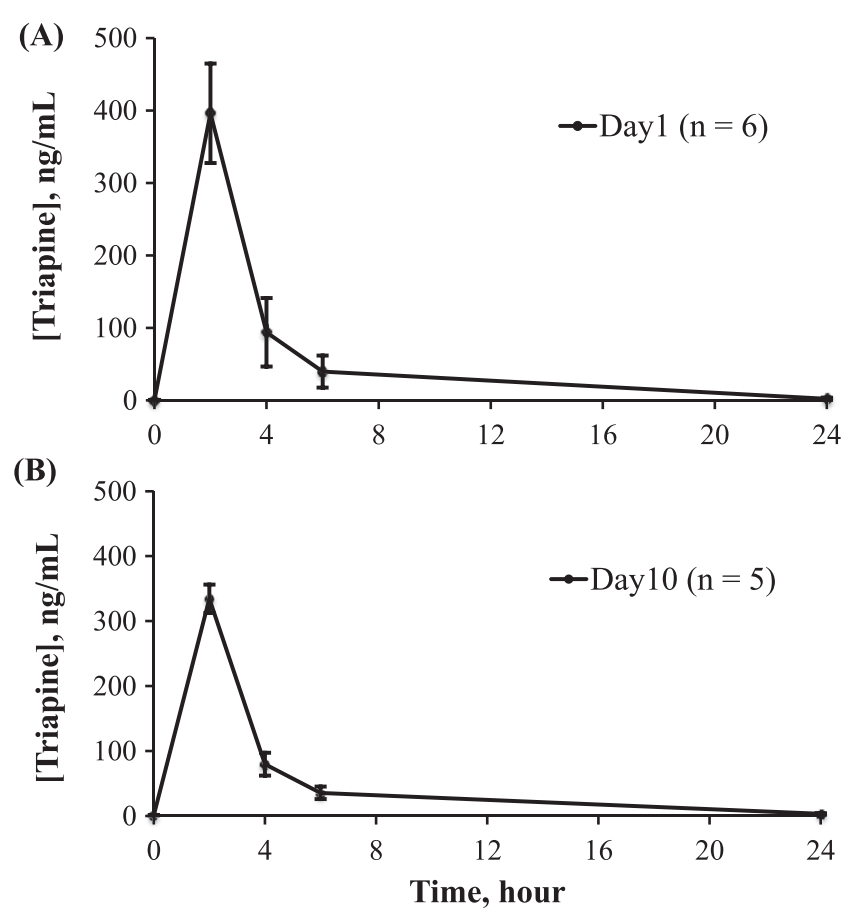

Figure 5. Mean triapine concentration time profiles of patients on days 1 and 10 by $2 \mathrm{~h}$ i.v. infusion of triapine at the dose of $25 \mathrm{mg} / \mathrm{m}^{2}$ three times per week for 5 weeks.

\section{Stability}

The stability study was conducted for triapine and the IS, and the results were summarized in Table 6 . At room temperature on the bench-top, tiapine and the IS stock solutions were stable for up to $24 \mathrm{~h}$, whereas triapine and the IS in plasma were stable for at least $6 \mathrm{~h}$. Triapine and the IS from plasma samples were stable in autosampler set at $4^{\circ} \mathrm{C}$ after sample preparation for $24 \mathrm{~h}$. The recoveries of triapine and the IS after three freeze-thaw cycles were $96 \%$ for the low QC and $98 \%$ for the high QC, respectively, whereas the recovery of the IS was $92 \%$. The studies also showed that there was no significant loss of triapine and the IS during long-term (30 days) storage at $-20^{\circ} \mathrm{C}$.

\section{Application of the method}

The feasibility of the LC-MS/MS method was demonstrated by the measurement of triapine concentrations in patient plasma samples collected from a previous phase I clinical trial of pelvic radiation, weekly cisplatin and triapine for locally advanced cervical cancer (Kunos et al., 2010a, 2010b). Figure 5 showed the triapine concentration-time profile in patients' blood samples on days 1 and 10 by $2 \mathrm{~h}$ triapine infusion at a dose of $25 \mathrm{mg} / \mathrm{m}^{2}$ three times a week for 5 weeks. Compared with the HPLC-UV method used in the previous work (Kunos et al., 2010a, 2010b), the LC-MS/MS method developed not only could produce a comparable triapine concentration-time profile, but also was capable of measuring triapine concentrations (i.e. $0 \mathrm{~h}$ 
on day 10, and $24 \mathrm{~h}$ on days 1 and 10) otherwise below the LLOQ of the HPLC-UV method $(20.0 \mathrm{ng} / \mathrm{mL})$. Therefore, the LC-MS/MS method is better suited for the clinical study of triapine, and has an unparalleled selectivity and LLOQ compared with the HPLC-UV method.

\section{Conclusion}

This work has provided a detailed discussion on the development and validation of an LC-MS/MS method for the quantitation of triapine in human plasma. The method employs a simple deproteinization protocol for sample preparation, a reversed-phase chromatograph for analyte separation and a tandem mass spectrometer for analyte quantitation. EDTA is used as anticoagulant and metal-ion chelator to prevent the unwanted complexation reaction between triapine and metal-ion interferents. This method has a linear calibration range of $0.250-50.0 \mathrm{ng} / \mathrm{mL}$ with the accuracy and precision well suited for analysis of human plasma samples, filling the gap between the needs of clinical trials and the less sensitive HPLC-UV method. It is useful for clinical studies of triapine in human.

\section{References}

Alvero AB, Chen W, Sartorelli AC, Schwartz P, Rutherford T and Mor G. Triapine ( 3 aminopyridine 2 carboxaldehyde thiosemicarbazone) in duces apoptosis in ovarian cancer cells. Journal of the Society for Gy necologic Investigation 2006; 13: 145152.

Bansal S and DeStefano A. Key elements of bioanalytical method valida tion for small molecules. The AAPS Journal 2007; 9: E109 114. DOI: 10.1208/aapsj0901011

Feng $\mathrm{Y}, \mathrm{McC}$ ulloch $\mathrm{M}$ and $\mathrm{Xu} \mathrm{Y}$. Development of a liquid chromato graphic method for quantitative determination of triapine, a ribonu cleotide reductase inhibitor, by spectrophotometric study of triapine complexation reaction. Journal of Liquid Chromatography and Related Technologies 2014; 37: 13511372.

Finch RA, Liu MC, Cory AH, Cory JG and Sartorelli AC. Triapine (3 aminopyridine 2 carboxaldehyde thiosemicarbazone; $3 \mathrm{AP}$ ): an in hibitor of ribonucleotide reductase with antineoplastic activity. Advances in Enzyme Regulation 1999; 39: 312.

Finch RA, Liu M, Grill SP, Rose WC, Loomis R, Vasquez KM, Cheng Y and Sartorelli AC. Triapine (3 aminopyridine 2 carboxaldehyde thiosemicarbazone): a potent inhibitor of ribonucleotide reductase activity with broad spectrum antitumor activity. Biochemical Pharma cology 2000; 59: 983991.

Giles FJ, Fracasso PM, Kantarjian HM, Cortes JE, Brown RA, Verstovsek S, Alvarado Y, Thomas DA, Faderl S, Garcia Manero G, Wright LP, Samson T, Cahill A, Lambert P, Plunkett W, Sznol M, DiPersio JF and Gandhi V. Phase I and pharmacodynamic study of Triapine, a novel ribonucleotide reductase inhibitor, in patients with advanced leuke mia. Leukemia Research 2003; 27: 10771083.

Jordan A and Reichard P. Ribonucleotide reductases. Annual Review of Biochemistry 1998; 67: 7198.
Kowol CR, Trondl R, Heffeter P, Arion VB, Jakupec MA, Roller A, Galanski $M$, Berger W and Keppler BK. Impact of metal coordination on cyto toxicity of 3 aminopyridine 2 carboxaldehyde thiosemicarbazone (triapine) and novel insights into terminal dimethylation. Journal of Medicinal Chemistry 2009; 52: 50325043.

Kunos CA, Chiu SM, Pink J and Kinsella TJ. Modulating radiation resis tance by inhibiting ribonucleotide reductase in cancers with virally or mutationally silenced p53 protein. Radiation Research 2009; 172: 666676.

Kunos CA, Radivoyevitch T, Pink J, Chiu SM, Stefan T, Jacobberger J and Kinsella TJ. Ribonucleotide reductase inhibition enhances chemoradiosensitivity of human cervical cancers. Radiation Research 2010a; 174: 574581.

Kunos CA, Waggoner S, von Gruenigen V, Eldermire E, Pink J, Dowlati A and Kinsella TJ. Phase I trial of pelvic radiation, weekly cisplatin, and 3 aminopyridine 2 carboxaldehyde thiosemicarbazone (3 AP, NSC \#663249) for locally advanced cervical cancer. Clinical Cancer Research 2010b; 16: 12981306.

Kunos CA, Radivoyevitch T, Waggoner S, Debernardo R, Zanotti K, Resnick K, Fusco N, Adams R, Redline R, Faulhaber P and Dowlati A. Radiochemotherapy plus 3 aminopyridine 2 carboxaldehyde thiosemicarbazone (3 AP, NSC \#663249) in advanced stage cervi cal and vaginal cancers. Gynecologic Oncology 2013; 130: 7580.

Kuo ML, Hwang HS, Sosnay PR, Kunugi KA and Kinsella TJ. Overexpres sion of the R2 subunit of ribonucleotide reductase in human naso pharyngeal cancer cells reduces radiosensitivity. The Cancer Journal 2003; 9: 277285.

Li J, Zheng LM, King I, Doyle TW and Chen SH. Syntheses and antitumor activities of potent inhibitors of ribonucleotide reductase: 3 amino 4 methylpyridine 2 carboxaldehyde thiosemicarba zone (3 AMP), 3 amino pyridine 2 carboxaldehyde thiosemicarbazone ( $3 \mathrm{AP}$ ) and its water soluble prodrugs. Current Medicinal Chemistry 2001; 8: 121133.

Mortazavi A, Ling Y, Martin LK, Wei L, Phelps MA, Liu Z, Harper EJ, Ivy SP, Wu X, Zhou BS, Liu X, Deam D, Monk JP, Hicks WJ, Yen Y, Otterson GA, Grever MR and Bekaii Saab T. A phase I study of prolonged infusion of triapine in combination with fixed dose rate gemcitabine in pa tients with advanced solid tumors. Investigational New Drugs 2013; 31: 685695 .

Murren J, Modiano M, Clairmont C, Lambert P, Savaraj N, Doyle T and Sznol M. Phase I and pharmacokinetic study of triapine, a potent ribo nucleotide reductase inhibitor, administered daily for five days in pa tients with advanced solid tumors. Clinical Cancer Research 2003; 9: 40924100.

Shao J, Zhou B, Chu B and Yen Y. Ribonucleotide reductase inhibitors and future drug design. Current Cancer Drug Targets 2006; 6: 409431.

US Food and Drug Administration. Guidance for Industry: Bioanalytical Method Validation, 2001. Available from: http:// http://www.fda. gov/downloads/Drugs/GuidanceComplianceRegulatorylnformation/ Guidances/UCM070107.pdf (accesed 14 December 2014).

Xu H, Fairman JW, Wijerathna SR, Kreischer NR, LaMacchia J, Helmbrecht E, Cooperman BS and Dealwis C. The structural basis for peptidomimetic inhibition of eukaryotic ribonucleotide reductase: a conformationally flexible pharmacophore. Journal of Medicinal Chem istry 2008; 51: 46534659.

Yee KW, Cortes J, Ferrajoli A, Garcia Manero G, Verstovsek S, Wierda W, Thomas D, Faderl S, King I, O'brien SM, Jeha S, Andreeff M, Cahill A, Sznol M and Giles FJ. Triapine and cytarabine is an active combina tion in patients with acute leukemia or myelodysplastic syndrome. Leukemia Research 2006; 30: 813822. 